\title{
LEGAL PROBLEMS ARISING OUT OF CO-OWNERSHIP OF OIL AND GAS LEASEHOLD ESTATE AND FACILITIES
}

\author{
MARTIN $M$. OLISA*
}

\begin{abstract}
Most joint venture agreements provide that the parties thereto shall own the joint property in undivided interests. If the agreement does not specify the rights and liabilities of the co-owners, resort must be had to general principles of the law of co-tenancy to determine the right of one co-tenant to drill for and produce oil and gas, the right of one co-tenant to the use of common facilities and the right of one co-tenant to alienate his interest. This article investigates these and related problems and concludes that, in the absence of legislation, there is no authoritative enunciation of the law governing the rights of co-tenants inter se in relation to oil and gas properties and facilities.
\end{abstract}

\section{A. INTRODUCTION}

Co-ownership, co-tenancy, concurrent interest and concurrent ownership are terms commonly used to denote joint ownership in property such that the co-owners are simultaneously entitled to the use and enjoyment of that property. ${ }^{2}$ A co-owner cannot lay claim to any part of the property as his own to the exclusion of other co-owners. The term "co-ownership" originated at early common law from dealings in real property and took the forms of joint tenancy, tenancy in common, tenancy by entireties and coparcenary. In modern transactions, co-ownership exists not only in land but also in chattels, oil and gas facilities, in a fund and in many other kinds of personal property. It may exist in fee simple, for life or for a fixed term. Co-ownership in personal property has been recognized in Alberta as follows:"

... It would appear on the authorities that concurrent ownership of chattels personal may be either joint or in common, and in this respect resembles concurrent interests in real estate; moreover, expressions contained in any instrument which at common law would create a joint tenancy or tenancy in common in realty, have an analıgous effect when applied to personalty. Furthermore, the right of survivorship attaches to a joint tenancy of personalty including choses in possession and in action as well as of realty until severance: ...

This article will consider the problems arising out of co-tenancy, particularly tenancy in common, in oil and gas leasehold estates, as well as in jointly owned oil and gas facilities. Since the law governing the rights and liabilities of co-tenants inter se developed at common law, was recognized in equity and was modified by statute, it is useful to refer briefly to relevant principles of real property law.

At early common law a co-tenant had the right to the possession of any part of the joint property and to the use and enjoyment of it in a proper manner. One co-tenant had no right to oust or evict the other or to destroy some part of the common property. Since no one co-owner

- B.Sc. (London), LL.B. (London), LL.M. (Alta.). Barrister. Middle Temple, member of the Law Society of Alberta; Sollcitor, Banff Oil Ltd., Calgary, Alberta.

1 Black's Law Dictionary (4th Ed.) defines co-tenancy as "a tenancy by several distinct titles but by unity of possession, or any joint ownership or common interest with its grantor. . The term is broad enough to comprise both tenancy in common and joint tenancy."

Concurrent ownership is defined as "a form of divided ownership where two or more persons own fractional, undivided interests in the whole." Williams and Meyers, Manual of Oil and Gas Terns, (New York: Matthew, Bender \& Company, 1964) p. 70.

2 Western Trust Company (Administrator of Sterenchuk Estate) v. Demchuk (1958) 26 W.W.R. 728 at 733. (1959) 16 D.L.R. 505 (Alberta A.D.). 
had a better right of possession than another, an action for trespass would not normally lie; ${ }^{3}$ only actual eviction of one by the other, or the destruction of any part of the common property would form the basis of an action at common law. Also, there was no obligation to account between joint tenants or tenants in common unless one co-tenant excluded the other from the common property or expressly contracted to act as bailiff of the other. ${ }^{*}$ Since the Statute of Westminster" a cotenant has been liable to his co-tenant for waste. Section 27 of the Statute of 4 Anne" (An Act for the Amendment of the Law and the better Advancement of Justice) provided that

Actions of Account shall and may be brought and maintained . . . by one joint tenant and tenant in common ... against the other as bailiff for receiving more than comes to his just share or proportion ....

The interpretation given by English courts to the above cited provision is that a co-tenant who receives from a third person payment of any kind in excess of his proportionate share according to his interest in the common property must account for the excess to his co-tenant.'

Thus the origin of the present law governing the rights and liabilities of a co-tenant to the use and enjoyment of property owned in common is to be found in the above English statutes. The Statute of Anne is in force in the common law provinces of Canada by virtue of the introduction of English law as of specific dates or by specific statutes. ${ }^{3}$ In Alberta, for example, section 15 of the Judicature Act ${ }^{9}$ gives the Supreme Court of Alberta the same jurisdiction as was vested in a Supreme Court of record in England on the 15th day of July, 1870. Specifically, section 16 gives the Supreme Court the same jurisdiction as was exercised by the Court of Chancery on the 15th day of July, 1870, in respect of accounts and the staying of waste.

\section{B. RIGHT OF A CO-TENANT TO DRILL FOR AND PRODUCE OIL AND GAS}

The right of one co-tenant to drill for and remove oil and gas from common property without the consent of his co-tenant appears to depend on whether or not the appropriate jurisdiction regards the extraction of oil and gas as waste.

\section{Majority Rule}

The generally prevailing rule, adhered to by all producing states in the United States except West Virginia, Illinois and Louisiana, is that the extraction of oil and gas from land is not waste but rather is a natural user of land. The extraction of oil and gas is the use rather than the destruction of the subject of tenancy. A co-tenant has the right to occupy the common property, drill for and remove oil and gas without the consent of his co-tenants, but he is not entitled to exclusive possession, use and enjoyment. ${ }^{10}$ The operating co-tenant must recognize his

3 Jacobs v. Seward (1872) 4 C.P. 328, 41 L.J.C.P. 221, cited with approval in Lehman v. Hunter (1939) 13 M.P.R. 553 (N.B.).

Spelman v. Spelman (1944) 2 D.L.R. 74; (1944) 1 W.W.R. 691,59 B.C.R. 551, (B.C.C.A.), citing Wheeler v. Horne (1740) Willes 208, 125 E.R. 1135.

5 (1285) 13 Edward 1, c. 22.

6 (1705) 4 Anne, c. 16

Henderson v. Eason (1851) 17 Q.B. 701, 117 E.R. 1451.

section 131 of the Judicature Act. R.S.O. 1960. c. 190 .

8 Spelman v. Spelman (1944) 2 D.L.R. 74; King v. King (1944) 4 D.L.R. 796, (1944)

3 W.W.R. 242 (Sask.). See also section 131 of the Judicature Act, R.S.O. 1960, c. 190 .

o R.S.A. 1955 , c. 164 . 
co-tenants' rights by not ousting them or denying them their right to drill and produce from the common property. His co-tenants cannot enjoin him on the ground that he is committing waste by his operations. If one of several owners takes out oil and gas, his co-tenants have a right to demand an accounting for the oil and gas taken out. ${ }^{11}$

\section{Minority Rule}

Among producing states in the United States, the minority rule is recognized by West Virginia, Louisiana and Illinois. It maintains that extraction of oil and gas is waste and forbids a co-tenant to take oil and gas from common property without the consent of his co-tenants. ${ }^{12}$ An injunction will lie at the suit of his non-consenting co-tenants. $\mathrm{He}$ is also under an obligation to account to his co-tenants if he removes oil and gas from the common property. As an exception to or modification of this rule, where the drilling by a co-tenant is undertaken to prevent undue drainage from common property by wells situated on adjoining lands, waste is "permitted". ${ }^{13}$ In some jurisdictions, for example, Illinois, where unauthorized extraction of oil and gas constitutes waste, a majority may obtain court permission to drill for and remove oil and gas which is being drained from common property. ${ }^{14}$

It appears that the majority rule is founded on equitable principles. The purpose of an oil and gas lease is the extraction of oil and gas and each of several co-tenants is entitled to the realization of this purpose. If a co-tenant is prohibited from undertaking oil and gas operations on common property by reason of his co-tenants' refusal to give their consent, he is deprived of the opportunity for the use and enjoyment of the interest he has in the common property. By giving him the right to drill and produce oil and gas from the common property and at the same time imposing upon him an obligation to compensate his co-tenant if he takes out oil and gas, an equitable adjustment of the conflicting rights of co-tenants in the common property is achieved. Furthermore, the majority rule is a manifestation of the policy of orderly and accelerated development of oil and gas resources within those states that adhere to the rule. In view of the establishment of such a policy in Alberta, and in view of the fact that leading United States authorities on oil and gas law are of strong persuasive value in Alberta, it is reasonable to expect that in proper cases, Alberta Courts will adopt and apply the majority rule unless there are very exceptional reasons for not doing so.

\section{Basis of Accounting}

If one of several owners produces oil and gas he must account to his co-tenants for the value of their respective interests in or shares of production. If the producing co-tenant does not oust his co-tenants or otherwise deny them their rights in the common property, he is allowed credit for the reasonable and necessary costs of prospecting and producing such shares. ${ }^{1:}$ This amounts to his paying to his co-tenants their

10 Earp v. Mid Continent Petroleum Corporation (1933) 167 Okla. 96, 27 P. 2 d 885.

11 See page 180 , below, for the basis of accounting to the non-consenting co-tenants.

12 Williamson v. Jones (1894) 43 W. Va. 562, 27 S.E. 411

13 Stroud v. Guffey (1927) 3 S.W. 2d 592 (Tex. Civ. App.).

14 Reward Oil Co. v. White (1948) 77 N.E. $2 d 436$ (IIl. App. Div).

1.5 Earp v. Mid Continent Petroleum Corporation (1933) 167 Okla. 96. 27 P. 2d 885 . See also Jones, Problems Presented by Joint Ownership of Oil. Gas and Other Minerals, 32 Texas Law Rev. 694 (954), reprinted in Oil and Gas Law, Vol. VII (Austin, Texas Law Review), pp. 2055-2087. 
proportionate shares of the net profits from the operation. In the absence of an agreement, non-consenting co-tenants are under no obligation to contribute to the costs of his operations. Even if production is obtained they are still under no personal duty to pay their proportionate shares of the costs but the operating co-tenant can recoup only out of production. ${ }^{1 \text { i }}$ Refusal by non-consenting co-tenants to pay their proportionate shares of the costs does not deprive them of their right to demand an accounting. It can be inferred from at least one decided case that so long as a co-tenant does not deny his co-tenants' rights in the common property, he has a legal right to undertake oil and gas operations on the common property even if such operations result in a dry hole causing a depreciation in the value of the property. ${ }^{17}$ Accordingly, such a co-tenant is not obligated to account to his co-tenants for any loss in value of the property occasioned by his drilling of a dry hole. This method of accounting is to be distinguished from the "royalty method" in which the damages payable by an innocent trespasser to an injured landowner is determined by the royalty rate customarily prevailing in the locality.

If the operating co-tenant ousts or evicts his co-tenants or otherwise denies them their rights in the common property he is treated as a trespasser with the result that, in accounting to his co-tenants, he is not allowed any credit for his expenditures. ${ }^{1 \times}$ The same rule applies where he otherwise takes or removes oil and gas wilfully or in bad faith. Good faith as applied to oil and gas operations has received the following definitions, namely:

Good faith consists in an honest intention to abstain from taking any unconscientious advantage of another, even through forms or technicalities of the law, together with an absence of all information or belief of facts which would render the transaction unconscientious. It is the opposite of fraud and its non-existence must be established by proof.19

... to act in good faith in developing a tract of land for oil or gas one must have an honest and reasonable belief in the superiority of his title.20

Finally, the operating co-tenant is entitled to reimbursement by the nonoperating co-tenants or a lien on their interest for expenditures by him for the preservation of the common property.

The basis of accounting outlined above is fundamentally that laid down by the Statute of 4 Anne with the following distinction; as stated in Henderson v. Eason," (an English case) and cited with approval in Spelman v. Spelman,": (a Canadian case) the statute applies to cases where one co-tenant receives:

(a) from a third party;

(b) the whole or part of any money payment or payment of any kind due to all the co-tenants;

1n Prairie Oil and Gas Co. v. Allen 2 F. 2d 566 (8th Cir. 1924)

17 Jones, Supra, n. 15 at 2068, citing Humble Oil \& Refining Co. v. Kishi (1925) 276 S.W. 190 (Tex. Comm. App.).

1. Willis, Thornton Oil and Gas, Vol. 2, 741 (5th ed. 1960).

19 Sapulpa Petroleum Co. v. McCray (1929) 136 Okla. 269, 277 Pac. 589. See also Black's Law Dictionary 822 (4th ed.).

20 Bailey v. Texus Pac. Coal \& Oil Co. (1934) 168 Okla. 275, 32 P. 2d 709.

21 (1851) 17 Q.B. 701, 117 E.R. 1451.

22 (1944) 2 D.L.R. 74, (1944) 1 W.W.R. 691,59 B.C.R. 511 (B.C.C.A.). 
(c) in excess of his proportionate share according to his interest in the subject of tenancy.

It does not apply to cases where the co-tenant "takes", as opposed to "receives", or where he "uses" the common property in excess of his interest therein. The statute does not mention land or any property in particular as the subject of tenancy. The wording is wide enough to include realty and personalty as the subject of co-tenancy. This was the view taken by English cases on the application of the statute.

\section{RIGHT OF A CO-TENANT TO USE COMMON FACILITIES}

The courts of most states in the United States with legislation similar to the Statute of 4 Anne, take a broader view of the provision than English courts, namely:

. . . a co-tenant is liable to account, not only for rents received from a third person (as in in England) but also for profits earned from a depletion of the land, as by mining, oil production or timber cutting. ${ }^{23}$

$\ldots$ an accounting is proper where a tenant in common uses the common property to the exclusion of his co-tenant or occupies and uses more than his just share or proportion. ${ }^{24}$

The writer is unable to find a clear statement of law from any Canadian authority regarding the relationship among co-tenants where one uses the subject of tenancy in excess of one's proportionate ownership. Put in the form of a question: does co-tenancy imply proportionate use and is liability for an accounting and an injunction attached to use by a co-tenant in excess of his proportionate share in the common property?:? "Use" in this context refers to those cases where a co-tenant avails himself or employs the services of the subject of tenancy in the absence of fiduciary relationship and without receiving payment of any kind from a third party for such use. An answer to this question is of practical importance in the co-ownership of plant, pipe line and battery facilities by lessee co-tenants. The opinion expressed below is at best a suggestion to a problem that was once described by $\mathrm{McDonald}$, C.J.B.C., in Spelman's case as one giving rise to "insuperable difficulties".

It is suggested that the answer depends on the kind of common property, the kind of use that is made of it and whether or not it is possible to render an account in respect of such excess use. In Spelman's case the Court of Appeal of British Columbia quoted Henderson v. Eason with approval as follows: ${ }^{20}$

There are obviously many cases in which a tenant in common may occupy and enjoy the land or other subject of tenancy in common solely, and have all the advantage to be derived from it, and yet it would be most unjust to make him pay anything. For instance, if a dwelling house, or barn, or room, is solely occupied by one tenant in common, without ousting the other, or a chattel is used by one co-tenant in common, nothing is received, and it would be most inequitable to hold that he thereby, by the simple act of occupation or use, without any agreement, should be liable to pay a rent or anything in the nature of compensation to his co-tenants for that occupation or use to which to the full extent to which he enjoyed it he had a perfect right. It appears impossible to hold that such a case could be within the [Statute of 4 Anne].

The facts of Spelman's case are as follows; the defendant, D, and the plaintiff, $\mathrm{P}$, were husband and wife, respectively. One of the issues in

23 Laskin. Cases and Notes on Land Law 389 (1958).

24 40 A.L.R. $1400(1926)$ Q

20 (1944) 2 D.L.R. 74 at 76-77. 
dispute concerned a house owned by the parties as joint tenants. For many years the parties lived together in the house, $P$ running a rooming house and apparently collecting money from roomers. Much of the money collected was spent in making mortgage payments on the house. $P$ left $D$ and the house. $D$ ran the rooming house and kept the takings. $P$ later returned to cohabitation and sued for an accounting of rent and profits. The judgment appealed from ordered both parties to account for rent and profits. It was held that the direction for an accounting must be set aside on the ground that the type of accounting contemplated was really impossible and must prove abortive.

It would appear that if it is possible to ascertain at what stage a cotenant has used up his proportionate share and it is also possible to quantify such use, a co-tenant whose proportionate share has been impaired has a prima facie right to restrain his co-tenant by injunction from further use, and, in addition, obtain compensation for the excess use by his co-tenant. However, as decided in Goodenow v. Farquhar, ${ }^{27}$ if damages are an adequate remedy, no injunction will be granted.

The above suggestions appear to be in line with a decision in another Canadian case, Proudfoot v. Bush."* This case concerned the cutting of timber by a co-tenant where the common land was suitable for timber only. The cutting operated as a destruction of the subject of tenancy. An injunction was granted against the co-tenant who had cut the timber, on the ground that acts of destructive waste will be restrained as between tenants in common. Another Canadian decision which supports the above submission is Hersey v. Murphy, wherein Grimmer, J. said: ${ }^{20}$

... when property is held by several persons as joint tenants or tenants in common, each has an equal right with his co-tenants to the entry and possession of the entire estate, and each co-tenant may use and enjoy the common property in a reasonable manner to the extent of his own interest, but cannot in any way impair or interfere with the equal right of his co-tenants to a similar use and enjoyment. What is a reasonable use depends upon the nature of the property and the fact that some of it is consumed or its value impaired by the use does not necesesarily render the use unlawful where such is a natural result of the usual and legitimate exercise of the right of enjoyment, as in the case of timber or mineral land held in common. If one tenant in common has used the property unlawfully or to the exclusion of his co-tenant he may become liable to the latter either in an action of tort for an accounting, or for possession, as the case may be. Also one co-tenant may license a stranger to use the property in such manner as would be permissible in himself, but such licence will not affect the interests or rights of the other co-tenants. Ordinarily one tenant in common of real property cannot maintain trespass quare clausum fregit against his co-tenant unless the act complained of amounts to an injury to or destruction of the common property or to the expulsion of the plaintiff from the property or an interference with his enjoyment thereof: ...

In Bull v. Bull, Lord Denning used an expression of similar import to the expressions, "in a reasonable manner" and "unlawfully" which appear in the above quotation from Hersey v. Murphy, as follows: ${ }^{30}$

... each of them [tenants in common] is entitled concurrently with the other to the possession of the land and to the use and enjoyment of it in a proper manner.... [Italics added.]

Bull v. Bull is not a Canadian authority as such, but the purpose of citing it is to suggest that in England it may well be that in a proper case, that is, where the use by one co-tenant is not "in a proper manner", the court may require a co-tenant who has used the subject of tenancy

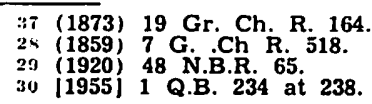


in excess of his proportionate ownership to make compensation to his co-tenant even in the absence of ouster of one by the other.

In common law jurisdictions of Canada, it appears that the trend is to broaden the application of the Statute of 4 Anne to include, as in the United States, those cases where a co-tenant uses common property as well as where he receives payment therefrom in excess of his proportionate share. In 1705, when the statute was enacted, problems of co-tenancy in oil and gas operations were obviously not within the contemplation of the English Parliament.

If a broadened interpretation of the Statute of 4 Anne is adopted, then as a general rule, co-ownership of oil and gas facilities implies use by co-tenants in proportions equivalent to the proportionate ownership in the facilities, but in most cases the implication will not be made on a day to day or on a piecemeal basis. Perhaps this principle is to be related to the totality of use made by a co-tenant. Thus, at a certain point in time, a co-tenant may use the facilities in excess of his equivalent proportionate share in the facilities, but by so doing he must neither interfere with the right of his co-tenants to use the facilities to the extent of their respective interests, nor lay exclusive claim to the use of a specified part of the common property. In other words, if his co-tenants do not require the use of the facilities, a co-tenant may exceed his "share" without being liable to his co-tenants for an accounting.

If a broadened interpretation of the Statute of 4 Anne is not adopted, then on strict principals of co-tenancy, a co-tenant may use the facilities in excess of his share in the common property without being liable to his co-tenants for an accounting unless he ousts them or denies them their rights.

There are occasions in which a co-owner of leasehold interests under a joint operating agreement may attempt to make use of jointly owned transportation, processing or other facilities to serve his independent operations. Such occasions may arise in consequence of the exercise of a number of options provided for in joint operating agreements. The issue is whether or not a co-tenant is entitled to use such facilities for his independent operations.

In any joint operations of oil and gas facilities in Alberta, the relationship amongst the co-owners is prima facie that of a mining partnership of which the co-owners are partners. Where the entity established for the operation is intended to be a partnership or is a partnership by the operation of law regardless of the intention of the co-owners, a partner who happens to be a co-tenant is not permitted, by reason of co-tenancy or as of right, to use partnership property for his own exclusive purpose. ${ }^{31}$ The practice in Alberta, however, is to include in a joint operating agreement a clause (Relation of Parties) designed to exclude the application of the law of partnership both as to the entity that is set up and as to the relationship of the parties to the agreement. The extent to which such a clause is effective in avoiding the consequences of partnership is not free from doubt. Are strangers to the agreement, for example, a person who supplied goods and services to

31 "Partnership property shall be held and applied by the partners exclusively for the purposes of the partnership and in accordance with the partnership agreement." The Partnership Act, R.S.A. 1955, c. 230, s. $22(1)$. 
the operator, bound by the provisions of such a clause? Is its application not limited, among other factors, to the subject of tenancy and the use made of it by co-tenants in their capacity as co-tenants? The answer depends on the provisions of the particular agreement and the facts of each particular case. Nevertheless, strangers to the agreement are not normally bound by such provisions.:2 Also, in respect of his independent operations, a co-tenant using common facilities for his own purpose is not in this respect a co-tenant of the other parties to the agreement. Situations have arisen in which an entity established for joint operation of oil and gas property has been declared to be a mining partnership, notwithstanding express provisions in the joint operating agreement designed to negative an intention to create a mining partnership. ${ }^{33}$

Whether or not a co-tenant using common facilities for his independent operations can invoke the provisions of the "Relation of Parties" clause to avoid partnership liability, his co-tenant may be right in maintaining that such use by the co-tenant is an improper and unreasonable exercise of the right of a co-tenant to use common facilities. Although a co-tenant has the right to use common facilities, yet it is doubtful if such a right extends to operations outside the joint operating agreement as well as outside the subject of co-ownership. In any event, no co-tenant is permitted to interfere with his co-tenants' right to the use and enjoyment of the facilities or to lay claim to exclusive use of a defined portion of the facilities.

\section{COMMINGLING}

In the United States, the doctrine of confusion is applied in cases of wrongful commingling of oil or gas. In Troop v. St. Louis Union Trust Co. et al.," $\mathrm{P}$ was manager and three-quarter owner and $\mathrm{D}$ was one-quarter owner of the working interest in an oil lease. $P$ was also owner and manager of a lease adjoining to the south. $P$ brought action to foreclose a partnership lien against $D$, alleging that $D$ had not contributed his share of operating expenses over a period of eight years. $D$ counterclaimed that $P$ had wrongfully commingled the oil from the partnership lease with that from P's lease to the south. The trial court entered a decree that $P$ had wrongfully commingled oil from the two leases, that it was impossible to determine how much of the oil from the partnership lease had been retained and not accounted for, and that the confusion of goods doctrine was applicable. On appeal it was held that the decree of the lower court properly awarded one fourth of the commingled oil to $D$, less the expenses properly charged. The decree was affirmed. The judgment declared as follows: ${ }^{3.7}$

The doctrine of confusion of goods has been a part of English and American law for continuous centuries. It applies to any type of goods of such uniformity that, after mixing, there is no possibility of identification of the component parts. If the proportionate parts are not ascertainable, equity will declare the innocent party owner of the whole...

... when the commingling is proved, the burden of going forward with evidence to show the correct proportions is on the party who commingled. In the absence of such proof he bears the whole loss.

32 See Williams and Meyers, Oil and Gas Law, Vol. 2, 508, foonote 3.

33 Id. at $499-503$.

34 (1960) 12 O. \& G.R. 1018, 166 N.E. 2d 116.

8i) Id. at 1025. 
It is probable that Alberta courts on similar facts will reach a similar decision to that in the Troop case.

\section{E. RIGHT OF A CO-TENANT TO ALIENATE HIS INTEREST}

A co-tenant may execute a lease conveying his interest in the common property. The lessee would then become a co-tenant with the excluded or non-consenting co-tenants during the term of the lease. Where the lessor is a joint tenant, there is a division of authority as to whether or not severance results from his leasing of his interest; in any event, the lease is good only as a transfer of the lessor's interest." If the lease is of the whole of the subject of tenancy, the other co-tenants could consent to the lease or ratify it and get their proportionate share of bonus, rentals and royalties. If the subject of the tenancy is a leasehold mineral interest and one of several co-tenants assigns his interest to a third person, as he has a right to do, the assignee succeeds to the right of possession and use in his assignor and becomes a co-tenant of the other co-tenants as to the minerals.

If one co-tenant leases or assigns the whole of the subject of tenancy or a defined part of it, his co-tenants are entitled to an injunction and an accounting against the lessee or assignee. They could, of course, join their co-tenant as a co-defendant and demand an accounting for payment received by him in the transaction. In Goodenow v. Farquhar, ${ }^{33}$ one of two tenants in common leased a defined part of land as a stone quarry. His co-tenant sued for an injunction and an accounting. The court held that his co-tenant was entitled to an injunction against further quarrying and to an accounting against the lessee for one moiety of the proceeds. It would appear that if damages were an adequate remedy in this case, damages in lieu of an injunction would have been awarded. This view was considered in the Ontario case of Mason v. Norris. ${ }^{3 *}$ The Plaintiff $(\mathrm{P})$ and $\mathrm{L}$ were tenants in common of an oil well. They constructed a tank, filled it with 24,000 barrels of oil, two-thirds of which was owned by $P$ and one-third by $L$. $P$ and $L$ agreed that the oil was not to be sold until $\$ 5$ per barrel could be procured for it. Thereafter, L sold to the defendants P's oil together with his own and the defendants were about to remove the oil from the tank when $P$ applied for an interlocutory injunction to restrain the defendants from removing the oil. The court held:

(1) that $L$ had no right to sell P's portion of the oil,

(2) that the defendant's removal of the oil would be wrongful, but

(3) an injunction was not granted because the "oil cannot be said to be of any peculiar value, being a staple commodity which can always be purchased, and therefore, property in respect of any damage compensation can be had at law, ${ }^{30}$ and

(4) that no fiduciary relationship existed between $P$ and $L$ or as regards $\mathrm{P}, \mathrm{L}$ and the defendants.

One of several co-tenants of a gas reservoir has the right to sell his proportionate share of gas even though his co-tenants, perhaps for

3i Vasiloff v. Johnson (1932) 41 O.W.N. 139.

37 (1873) Gr. Ch. R. 164.

38 (1871) $18 \mathrm{Gr}$. Ch. R. 500 (Chancery Div. Ont.).

38 Id. at 501 . 
reason of low price, are unwilling to sell their share. A problem facing his co-tenants if they decide to oppose the sale is that until the reservoir is depleted, it is probably impossible to state with any degree of certainty, the quantity of recoverable gas that belongs to each of the co-tenants in accordance with that co-tenant's percentage ownership of the reservoir. The co-tenants not willing to sell can, however, maintain that the daily quantity of gas sold by their co-tenant contains their proportionate share of gas, thereby raising the question of whether or not they can stop their co-tenant from selling their share of gas or any gas at all. If the majority view as stated earlier is accepted, they will not be granted an injunction against their co-tenant to stop him from selling the gas. Their co-tenant may sell the gas on condition that, firstly, he accounts to his co-tenants for the value of their proportionate share of gas from time to time sold by him and, secondly, he must not in any way interfere with the right of his co-tenants to sell their proportionate shares of gas. It is assumed that the co-tenants are not under an agreement restricting the right of any of them to sell the gas that is under common ownership.

\section{F. CONCLUSION}

This article is not a complete review of the problems of co-ownership of oil and gas leasehold interests and facilities. One conclusion that emerges rather prominently from this article is the absence of clear authoritative enunciation of the law governing the rights and the relationships of co-tenants inter se in relation to oil and gas property and facilities in Alberta, and for that matter, in Canada. It is to be hoped that legislation will be forthcoming to lay down the guidelines, designed for example, to clarify the right or the absence of it, of one of several co-tenants to produce oil and gas from common property in the absence of the consent of his co-tenants; to set out the obligations for and the basis of accounting among co-tenants where one co-tenant uses common facilities or produces without the consent of his co-tenants; to state unequivocally whether or not oil and gas leases may be partitioned in kind and under what circumstances; ${ }^{40}$ and to provide for the possible relationships such as partnerships, fiduciary capacity and agency, that may exist among co-tenants in the course of oil and gas operations as well as under what circumstances such relationships will arise or be implied. There are statutes in many jurisdictions, particularly in the United States, covering these matters. It must be recognized, however, that in nearly all producing countries of the world, the oil and gas law frequently lags behind the legal guidelines that the oil and gas industry considers adequate. Where the relationship between the industry and the government is one of co-operation and understanding, as it is in Alberta, changes are often made in the law so that it may keep pace with the methods and techniques of the industry. 